\title{
PENGARUH OLAH TANAH DAN PEMUPUKAN TERHADAP PERTUMBUHAN, PRODUKSI, DAN HARA TERANGKUT (C, N, P, K) TANAMAN KACANG HIJAU (Vigna radiata L.)
}

\section{THE EFFECT OF TILLAGE AND FERTILIZATION ON THE GROWTH, PRODUCTION, AND TRANSPORTED NUTRIENTS (C, N, P, K) ON MUNG BEAN PLANT (Vigna radiata L.)}

\author{
Zelviana Putri ${ }^{1 *}$, Jamalam Lumbanraja ${ }^{1}$, Hery Novpriansyah ${ }^{2}$ dan Muhajir Utomo ${ }^{2}$ \\ ${ }^{1}$ Jurusan Agroteknologi, ${ }^{2}$ Jurusan Ilmu Tanah Fakultas Pertanian Universitas Lampung, \\ Bandarlampung, Indonesia \\ Email: zelviana.putri96@gmail.com
}

* Corresponding Author, Diterima: 2 Okt. 2021 , Direvisi: 19 Okt. 2021 , Disetujui: 25 Nov. 2021

\begin{abstract}
This research aimed to find out the effect of tillage and fertilization on the growth, production, and transported nutrients $(C, N, P, K)$ of mung bean plant (Vigna radiata L.). This research was conducted at the Integrated Field Laboratory, Faculty of Agriculture, Lampung University and analysis of mung bean samples was conducted at the Laboratory of Soil Science, Faculty of Agriculture, University of Lampung from April to May 2018. The research was conducted with a factorial a completely randomized design (CRD) $(2 \times 2)$ with 4 replications. The treatment factor applied was soil process $(T)$ which consisted of minimum soil process (T0) and intensive soil process (T1), while fertilization treatment $(P)$ consisted of non-fertilization (P0) and with fertilization of Phonska $200 \mathrm{~kg} \mathrm{ha-1}$ and compost $1 \mathrm{Mg}$ ha-1 (P1). Observational data was analyzed by ANARA, and continued with the BNT test at the level of 5\%. The results showed that OTM treatment was able to increase the dry weight of the stem, transported nutrient $N$ (seeds, leaves, stems, and total), transported nutrient $P$ (stem and total), transported nutrient $K$ (pods, leaves, and stems), and transported nutrient $C$ (leaves and stems) compared to intensive soil treatment. The fertilization treatment of NPK compound fertilizer $200 \mathrm{~kg} \mathrm{ha-1}$ and compost $1 \mathrm{Mg}$ ha-1 had an influence on increasing plant height, mung bean seed production, dry weight of mung been seeds, transported nutrient $P$ (seeds and pods), and transported nutrient $C$ (pods) compared to treatment without fertilizer.
\end{abstract}

Keywords: Fertilization, growth, mung bean, production, tillage, transported nutrients.

\section{ABSTRAK}

Penelitian ini bertujuan untuk mengetahui pengaruh olah tanah dan pemupukan terhadap pertumbuhan, produksi, dan hara terangkut $(\mathrm{C}, \mathrm{N}, \mathrm{P}, \mathrm{K})$ tanaman kacang hijau (Vigna radiata $\mathrm{L}$.). Penelitian ini dilaksanakan di Laboratorium Lapang Terpadu, Fakultas Pertanian, Universitas Lampung dan analisis sampel tanaman kacang hijau dilakukan di Laboratorium Ilmu Tanah, Fakultas Pertanian, Universitas Lampung dari bulan April sampai dengan Mei 2018. Penelitian dilaksanakan dengan Rancangan Acak Kelompok(RAK) faktorial (2 x 2) dengan 4 ulangan. Faktor perlakuan yang diterapkan yaitu olah tanah (T) yang terdiri dari olah tanah minimum (T0) dan olah tanah intensif (T1), sedangkan perlakuan pemupukan (P) yaitu terdiri dari tanpa pemupukan (P0) dan dengan pemupukan phonska $200 \mathrm{~kg}$ ha-1 dan kompos $1 \mathrm{Mg}$ ha-1 (P1). Data hasil pengamatan dianalisis dengan ANARA, dan dilanjutkan dengan uji BNT pada taraf 5\%. Hasil penelitian menunjukan bahwa, perlakuan OTM mampu meningkatkan bobot kering batang, hara $\mathrm{N}$ terangkut (biji, daun, batang, dan total), hara $\mathrm{P}$ terangkut (batang dan total), hara $\mathrm{K}$ terangkut (polong, daun, dan batang), serta hara $\mathrm{C}$ terangkut (daun dan batang) dibandingkan perlakuan olah tanah intensif. Perlakuan pemupukan pupuk majemuk NPK $200 \mathrm{~kg}$ ha-1 dan kompos $1 \mathrm{Mg}$ ha-1 berpengaruh meningkatkan tinggi tanaman, produksi biji kacang hijau, bobot kering biji kacang hijau, hara $\mathrm{P}$ terangkut (biji dan polong), serta hara $\mathrm{C}$ terangkut (polong) dibandingkan perlakuan tanpa pupuk.

Kata kunci: Hara terangkut, kacang hijau, olah tanah, pemupukan, pertumbuhan, produksi. 


\section{PENDAHULUAN}

Kacang hijau (Vigna radiata L.) merupakan salah satu tanaman yang tergolong dalam familly Leguminosa yang banyak di konsumsi oleh masyarakat di Indonesia. Produksi kacang hijau di Provinsi Lampung mengalami penurunan selama empat tahun terakhir. Pada tahun 2016 produksi kacang hijau mencapai 1,347 juta Mg (megagram) kemudian pada tahun 2017 produksi kacang hijau menurun yaitu 1,265 juta Mg. Produksi kacang hijau pada tahun 2018 sama seperti tahun sebelumnya yaitu 1,265 juta $\mathrm{Mg}$ dan pada tahun 2019 produksi kacang hijau menurun menjadi 1,062 juta $\mathrm{Mg}$ (Badan Pusat Statistik, 2019). Upaya yang dapat dilakukan untuk meningkatkan produksi kacang hijau yaitu dengan ekstensifikasi dan intensifikasi lahan pertanian.

Ekstensifikasi merupakan upaya peningkatan produksi pertanian dengan cara menambah luas lahan. Akan tetapi, lahan pertanian di Indonesia semakin berkurang karena adanya alih fungsi lahan seperti pembangunan infrastruktur dan pembangunan pemukiman, sehingga upaya peningkatan produksi dengan cara ekstensifikasi pertanian kecil kemungkinannya.

Intensifikasi lahan pertanian merupakan upaya meningkatkan produksi pertanian dengan berbagai cara seperti pengolahan tanah, pemupukan, pemberantasan hama dan penyakit, penggunaan bibit unggul, dan pengaturan irigasi. Cara yang dapat dilakukan yaitu dengan pengolahan tanah dan pemupukan. Para petani di Indonesia saat ini lebih cenderung melakukan Olah Tanah Intensif (OTI) untuk mendapatkan hasil produksi semaksimal mungkin. Pengolahan tanah dengan OTI dapat membantu pertumbuhan dan perkembangan tanaman secara optimal, tetapi dampak positif tersebut hanya sementara karena untuk jangka panjang akan berdampak negatif terhadap produktivitas lahan dan tanaman. Mengingat dampak yang ditimbulkan oleh OTI, maka dapat dilakukan Olah Tanah Konservasi (OTK) salah satunya yaitu Olah Tanah Minimum (OTM).

Menurut Utomo (1995), pada percobaan jangka panjang di Lampung menunjukkan OTK salah satunya yaitu OTM mampu memperbaiki kesuburan tanah lebih baik dari OTI, sehingga diharapkan OTM dapat meningkatkan pertumbuhan dan perkembangan tanaman diikuti produksi yang dapat meningkat juga

Menurut Kariyasa (2005), pemupukan dapat menyediakan unsur hara yang diperlukan tanaman untuk mendorong pertumbuhan, meningkatkan produksi, dan memperbaiki kualitas tanah. Pupuk phonska dapat meningkatkan produksi tanaman karena pupuk ini hampir seluruhnya larut dalam air, sehingga unsur hara yang dikandungnya dapat segera diserap dan digunakan oleh tanaman dengan efektif(Kaya, 2013).

Penggunaan pupuk anorganik secara terus menerus dapat menurunkan kualitas tanah. Oleh karena itu, penggunaan pupuk anorganik dapat dikombinasikan dengan pupuk organik seperti kompos. Pemberian pupuk organik dan pupuk anorganik secara bersama- sama akan saling melengkapi unsur hara yang dibutuhkan tanaman dalam menunjang pertumbuhan dan produksi tanaman (Sirappa, dkk., 2005). Penelitian ini bertujuan untuk mengetahui pengaruh olah tanah dan pemupukan terhadap pertumbuhan, produksi, dan hara terangkut $(\mathrm{C}, \mathrm{N}, \mathrm{P}, \mathrm{K})$ tanaman kacang hijau (Vigna radiata $\mathrm{L}$.).

\section{BAHAN DAN METODE}

Penelitian dilaksanakan di Laboratorium Lapang Terpadu, Fakultas Pertanian, Universitas Lampung yang terletak pada 5Ú22'04,5" LS dan 105Ú14'42,7" BT dengan ketinggian $106 \mathrm{~m}$ dpl. Penelitian ini dilaksanakan dari bulan April sampai dengan Juni 2017. Analisis sampel tanaman kacang hijau dilakukan dari bulan April sampai dengan Mei 2018 di Laboratorium Ilmu Tanah, Fakultas Pertanian, Universitas Lampung.

Alat-alat yang digunakan dalam penelitian ini adalah cangkul, buku pengamatan, pena, meteran, selang air, spectrophotometer, flame photometer, dan lain-lain. Bahan yang digunakan dalam penelitian ini adalah benih kacang hijau, pupuk phonska, pupuk kompos, dan bahan-bahan kimia untuk analisis tanaman. Penelitian dilaksanakan dengan menggunakan Rancangan Acak Kelompok (RAK) dengan perlakuan yang disusun secara faktorial $(2 \times 2)$ dengan masing-masing petak percobaan berukuran $2,5 \mathrm{~m}$ x 2,5 $\mathrm{m}$. Perlakuan yang diterapkan terdiri dari 2 faktor. Faktor pertama yaitu olah tanah (T) yang terdiri dari OTM (T0) dan OTI (T1). Faktor kedua yaitu pemupukan (P) yang terdiri dari tanpa pemupukan $(\mathrm{P} 0)$ dan dengan pemupukan (P1) NPK Phonska $200 \mathrm{~kg}$ ha-1 dan kompos 1 $\mathrm{Mg}$ ha-1. Dari kedua faktor tersebut diperoleh 4 kombinasi perlakuan dan dilakukan dengan 4 kali ulangan, sehingga diperoleh 16 satuan percobaan.

Variabel pengamatan pada penelitian ini yaitu tinggi tanaman, bobot biji setelah panen, bobot 
brangkasan kering oven, dan analisis jaringan tanaman.

Analisis unsur hara menggunakan metode Corganik (metode Walkley dan Black), N-total (metode Kjeldahl), P-tersedia (metode blue molibdenum), dan $\mathrm{K}$ tanaman (metode pengabuan kering) (Thom dan Utomo, 1991). Data hasil pengamatan diuji dengan analisis ragam. Apabila pengaruh perlakuan terhadap variabel nyata, perbedaan nilai rata-rata dari variabel pada masing-masing perlakuan akan diuji lanjut menggunakan Uji BNT (Beda Nyata Terkecil) pada taraf nyata 5\% (Susilo, 2013).

\section{HASIL DAN PEMBAHASAN}

\subsection{Pertumbuhan Vegetatif Tanaman Kacang Hijau}

\subsubsection{Tinggi tanaman kacang hijau}

Hasil analisis ragam menunjukkan bahwa perlakuan pemupukan memberikan pengaruh yang nyata terhadap tinggi tanaman kacang hijau. Berdasarkan hasil uji BNT (Tabel 1) perlakuan P1 menunjukkan tanaman kacang hijau tertinggi yaitu $36,63 \mathrm{~cm}$ yang berbeda nyata dengan perlakuan
P0 (tanpa dipupuk) yaitu $32,38 \mathrm{~cm}$. Pertumbuhan tinggi tanaman ini disebabkan oleh penggunaan pupuk. Penggunaan pupuk dapat menambah unsur hara di dalam tanah sehingga dapat menyediakan unsur hara bagi pertumbuhan tanaman. Penelitian (Nainggolan, dkk., 2017) menunjukkan pemberian pupuk NPK dapat meningkatkan tinggi tanaman kedelai dan menjadi perlakuan terbaik dalam meningkatkan tinggi tanaman.

\subsubsection{Jumlah daun}

Hasil analisis ragam menunjukkan perlakuan olah tanah, perlakuan pemupukan, dan interaksi tidak berpengaruh nyata terhadap jumlah daun kacang hijau. Jumlah daun tertinggi yaitu pada perlakuan $\mathrm{T} 1$ (olah tanah intensif) dan P1 (pemberian pupuk) yaitu 26, kemudian diikuti perlakuan T0 (olah tanah minimum) 25 dan P0 (tanpa pupuk) 24 (Tabel 2).

\subsubsection{Produksi tanaman kacang hijau}

Tabel 3 menunjukkan bahwa, perlakuan P1 (pemberian pupuk) menghasilkan bobot biji kacang hijau setelah panen tertinggi sebesar $0,88 \mathrm{Mg}$ ha-1

Tabel 1. Pengaruh Olah Tanah Dan Pemupukan Terhadap Tinggi Tanaman Kacang Hijau 5 MST.

\begin{tabular}{cc}
\hline Perlakuan & Tinggi Tanaman 5 MST (cm) \\
\hline T0 (olah tanah minimum) & 36,07 \\
T1 (olah tanah intensif) & 32,96 \\
\hline UJI F $\quad$ tn \\
\hline BNT 5\% & - \\
\hline P0 (tanpa pupuk) & $32,38 \mathrm{~b}$ \\
P1 (pemberian pupuk) & $36,63 \mathrm{a}$ \\
\hline UJI F & $*$ \\
\hline BNT 5\% & 3,32 \\
\hline
\end{tabular}

Keterangan : $\mathrm{tn}=$ tidak berbeda nyata pada taraf $5 \%,{ }^{*}=$ berbeda nyata pada taraf $5 \%$, Kolom yang diikuti dengan huruf yang sama tidak berbeda nyata pada uji BNT taraf $5 \%$, MST $=$ minggu setelah tanam.

Tabel 2. Pengaruh Olah Tanah dan Pemupukan terhadap Jumlah Daun Kacang Hijau 5 MST.

\begin{tabular}{cc}
\hline Perlakuan & Jumlah Daun 5 MST (helai) \\
\hline T0 (olah tanah minimum) & 25 \\
T1 (olah tanah intensif) & 26 \\
\hline UJI F & tn \\
\hline BNT 5\% & - \\
\hline P0 (tanpa pupuk) & 24 \\
P1 (pemberian pupuk) & 26 \\
\hline UJI F & tn \\
\hline BNT 5\% & - \\
\hline
\end{tabular}

Keterangan $:$ tn $=$ tidak berbeda nyata pada taraf $5 \%, *=$ berbeda nyata pada taraf $5 \%$, Kolom yang diikuti dengan huruf yang sama tidak berbeda nyata pada uji BNT taraf $5 \%$, MST $=$ minggu setelah tanam. 
yang berbeda nyata denganperlakuan P0 (tanpa dipupuk) yaitu $0,74 \mathrm{Mg}$ ha-1. Tingginya hasil produksi pada perlakuan pemberian pupuk dikarenakan dengan penambahan pupuk ke dalam tanah maka ketersediaan hara di dalam tanah akan meningkat juga. Peningkatan hara di dalam tanah akan berpengaruh baik terhadap pertumbuhan tanaman sehingga produksi kacang hijau meningkat juga. Hal ini sejalan dengan penelitian Hapsoh, dkk., (2019), produksi kacang kedelai tertinggi yaitu dengan dosis pupuk NPK $250 \mathrm{~kg}$ ha-1 dibandingkan dengan perlakuan lainnya.

Tabel 4 menunjukkan bahwa, bobot kering oven biji kacang hijau tertinggi terdapat pada perlakuan tanpa dipupuk yaitu $0,39 \mathrm{Mg}$ ha- 1 . Hal ini diduga pemberian pupuk NPK majemuk sesuai rekomendasi yaitu dengan dosis $200 \mathrm{~kg}$ ha-1 mampu menghasilkan bobot kering oven biji tertinggi. Selain itu pupuk kompos mengandung hara N yang dibutuhkan untuk tanaman. Menurut Meirina (2009) unsur N yang terdapat dalam pupuk merupakan penyusun bahan organik dalam biji seperti asam amino, protein, koenzim, klorofil dan sejumlah bahan lain dalam biji, sehingga pemberian pupuk yang mengandung $\mathrm{N}$ pada tanaman akan meningkatkan bobot kering biji.

Tabel 4 menunjukkan bobot kering batang kacang hijau tertinggi terdapat pada perlakuan T0 yaitu $0,39 \mathrm{Mg}$ ha-1. Hal ini karena pada olah tanah minimum terdapat mulsa yang dapat menekan laju evaporasi tanah dan meningkatkan ketersediaan air tanah. Sebagaimana yang dikemukakan oleh Rachman. dkk., (2004) yang menyatakan pada perlakuan olah tanah minimum dapat mengurangi evaporasi dan meningkatkan infiltrasi yang menyebabkan kandungan air tanah lebih tinggi disekitar daerah perakaran tanaman dibandingkan olah tanah intensif. Sehingga tanaman dapat tumbuh dengan menyerap air dan hara secara optimal sehingga diperoleh bobot kering batang yang tinggi.

\subsection{Hara Terangkut Tanaman Kacang Hijau}

\subsubsection{Nitrogen $(N)$}

Tabel 5 menunjukkan hara $\mathrm{N}$ terangkut pada biji, daun, batang, dan total tertinggi terdapat pada

Tabel 3. Pengaruh Olah Tanah dan Pemupukan terhadap Bobot Biji Kacang Hijau Setelah Panen.

\begin{tabular}{cc}
\hline Perlakuan & Bobot biji $\left(\mathrm{Mg} \mathrm{ha}^{-1}\right)$ \\
\hline T0 (olah tanah minimum) & 0,83 \\
T1 (olah tanah intensif) & 0,79 \\
\hline UJI F $\quad$ tn \\
\hline BNT 5\% & - \\
\hline P0 (tanpa pupuk) & $0,74 \mathrm{~b}$ \\
P1 (pemberian pupuk) & 0,88 a \\
\hline UJI F & $*$ \\
\hline BNT 5\% & 0,06 \\
\hline
\end{tabular}

Keterangan $: \mathrm{tn}=$ tidak berbeda nyata pada taraf $5 \%, *=$ berbeda nyata pada taraf $5 \%$, Kolom yang diikuti dengan huruf yang sama tidak berbeda nyata pada uji BNT taraf $5 \%$, MST $=$ minggu setelah tanam.

Tabel 4. Pengaruh Olah Tanah dan Pemupukan terhadap Bobot Kering Oven Tanaman Kacang Hijau.

\begin{tabular}{|c|c|c|c|c|c|}
\hline Perlakuan & $\begin{array}{c}\text { Bobot kering } \\
\text { Biji }\end{array}$ & $\begin{array}{c}\text { Bobot kering } \\
\text { daun }\end{array}$ & $\begin{array}{c}\text { Bobot kering } \\
\text { polong }\end{array}$ & $\begin{array}{c}\text { Bobot kering } \\
\text { batang }\end{array}$ & Total \\
\hline \multicolumn{6}{|c|}{$\mathrm{Mg} \mathrm{ha}^{-1}$} \\
\hline T0 (olah tanah minimun) & 0,41 & 0,09 & 0,20 & $0,39 \mathrm{a}$ & 1,08 \\
\hline T1 (olah tanah intensif) & 0,49 & 0,08 & 0,19 & $0,28 \mathrm{~b}$ & 1,04 \\
\hline UJI F & tn & tn & tn & $*$ & tn \\
\hline BNT 5\% & - & - & - & 0,09 & - \\
\hline P0 (tanpa pupuk) & $0,39 \mathrm{~b}$ & 0,09 & 0,19 & 0,34 & 1,00 \\
\hline P1 (pemberian pupuk) & $0,51 \mathrm{a}$ & 0,08 & 0,20 & 0,33 & 1,12 \\
\hline UJI F & $*$ & tn & tn & tn & tn \\
\hline BNT 5\% & 0,11 & - & - & - & - \\
\hline
\end{tabular}

Keterangan $: \operatorname{tn}=$ tidak berbeda nyata pada taraf $5 \%, *=$ berbeda nyata pada taraf $5 \%$, Kolom yang diikuti dengan huruf yang sama tidak berbeda nyata pada uji BNT taraf $5 \%$, MST = minggu setelah tanam. 
perlakuan OTM (T0) pada biji yaitu 16,56 kg ha-1, daun yaitu 2,28 kg ha-1, batang yaitu 5,21 kg ha-1, dan total $26,17 \mathrm{~kg}$ ha-1. Olah tanah minimum menggunakan serasah tanaman yang digunakan sebagai mulsa. Menurut Rachman, dkk., (2004) mulsa dipermukaan tanah mampu mengurangi penyumbatan pori sehingga dapat meningkatkan volume air yang terinfiltrasi sehingga ketersediaan air di daerah perakaran tanaman lebih banyak dibandingkan perlakuan olah tanah intensif. Ketersediaan air yang cukup dapat menunjang proses metabolisme tanaman serta meningkatkan hasil serapan hara. Selain itu, tingginya serapan $\mathrm{N}$ tanaman berkaitan dengan tingginya bobot kering tanaman, semakin besar hasil produksi biji maka semakin besar juga hara $\mathrm{N}$ yang diserap. Peningkatan serapan N pada tanaman kacang hijau juga berkaitan dengan bobot kering tanaman, semakin tinggi bobot kering tanaman maka kandungan hara $\mathrm{N}$ yang diserap juga tinggi.

\subsubsection{Fosfor (P)}

Tabel 6 menunjukkan bahwa, hara $\mathrm{P}$ terangkut tertinggi pada biji dan polong terdapat pada perlakuan P1 yaitu 1,25 kg ha-1 dan 0,16 kg ha-1. Tingginya hara $\mathrm{P}$ pada perlakuan pemupukan yaitu hal ini dapat disebabkan oleh hara $P$ yang dibutuhkan tanaman sebagai bahan dasar protein dalam proses pembentukan ATP dan ADP pada proses metabolisme tanaman. Hara P mampu merangsang pembentukan bunga, buah, dan biji, serta dapat mempercepat pemasakan buah dan biji yang lebih berbobot (Yusuf dkk., 2017). Selain itu, penambahan pupuk dan bahan organik pada tanah dapat meningkatkan ketersediaan P untuk tanaman, bahan oganik di dalam tanah berperan untuk pembentukan kompleks organofosfat yang mudah diasimilasi oleh tanaman, penyelimutan oksida Fe dan $\mathrm{Al}$ oleh humus yang membentuk lapisan pelindung dan mengurangi jerapan $\mathrm{P}$ dan dapat meningkatkan $P$ organik yang dimineralisasi oleh $P$ kimia (Halvin dkk., 1999).

Tabel 6 menunjukkan hara P terangkut pada batang dan total tertinggi terdapat pada perlakuan T0 yaitu 0,37 kg ha-1 dan $1,75 \mathrm{~kg}$ ha-1 Rendahnya hara $\mathrm{P}$ terangkut pada olah tanah intensif dapat terjadi karena hara $\mathrm{P}$ terikat dengan $\mathrm{Al}$ dan $\mathrm{Fe}$. Hal ini sejalan dengan penelitian Kusumastuti, dkk., (2018) pada olah tanah intensif tanah diolah secara

Tabel 5. Pengaruh Olah Tanah dan Pemupukan terhadap Hara N Terangkut pada Tanaman Kacang Hijau.

\begin{tabular}{|c|c|c|c|c|c|}
\hline \multirow{2}{*}{ Perlakuan } & \multicolumn{5}{|c|}{ Hara $\mathrm{N}$ terangkut $\left(\mathrm{kg} \mathrm{ha}^{-1}\right)$} \\
\hline & Biji & Polong & Daun & Batang & Total \\
\hline T0 (olah tanah minimun) & $16,56 \mathrm{a}$ & 1,45 & $2,28 \mathrm{a}$ & $5,21 \mathrm{a}$ & $26,17 \mathrm{a}$ \\
\hline T1 (olah tanah intensif) & $14,72 \mathrm{~b}$ & 1,70 & $0,68 \mathrm{~b}$ & $2,83 \mathrm{~b}$ & $19,93 \mathrm{~b}$ \\
\hline UJI F & $*$ & tn & $*$ & $*$ & $*$ \\
\hline BNT 5\% & 1,67 & - & 0,37 & 0,94 & 2,07 \\
\hline P0 (tanpa pupuk) & 16,19 & 1,41 & 1,33 & 3,91 & 22,85 \\
\hline P1 (pemberian pupuk) & 15,10 & 1,74 & 1,62 & 4,12 & 23,25 \\
\hline UJI F & tn & tn & tn & $\operatorname{tn}$ & tn \\
\hline BNT 5\% & - & - & - & - & - \\
\hline
\end{tabular}

Keterangan : $\operatorname{tn}=$ tidak berbeda nyata pada taraf $5 \%, *=$ berbeda nyata pada taraf $5 \%$, Kolom yang diikuti dengan huruf yang sama tidak berbeda nyata pada uji BNT taraf $5 \%$, MST $=$ minggu setelah tanam.

Tabel 6. Pengaruh Olah Tanah dan Pemupukan terhadap Hara P Terangkut pada Tanaman Kacang Hijau.

\begin{tabular}{lccccc}
\hline \multirow{2}{*}{ Perlakuan } & \multicolumn{5}{c}{ Hara P terangkut $\left(\mathrm{kg} \mathrm{ha}^{-1}\right)$} \\
\cline { 2 - 6 } & Biji & Polong & Daun & Batang & Total \\
\hline T0 (olah tanah minimun) & 1,06 & 0,16 & 0,08 & $0,37 \mathrm{a}$ & $1,75 \mathrm{a}$ \\
T1 (olah tanah intensif) & 1,15 & 0,13 & 0,07 & $0,26 \mathrm{~b}$ & $1,53 \mathrm{~b}$ \\
\hline UJI F & tn & tn & tn & $*$ & $*$ \\
\hline BNT 5\% & - & - & - & 0,08 & 0,21 \\
\hline P0 (tanpa pupuk) & $0,95 \mathrm{~b}$ & $0,13 \mathrm{~b}$ & 0,08 & 0,32 & 1,57 \\
P1 (pemberian pupuk) & $1,25 \mathrm{a}$ & $0,19 \mathrm{a}$ & 0,07 & 0,31 & 1,72 \\
\hline UJI F & $*$ & $*$ & tn & tn & tn \\
\hline
\end{tabular}

Keterangan : tn $=$ tidak berbeda nyata pada taraf 5\%, *= berbeda nyata pada taraf $5 \%$, Kolom yang diikuti dengan huruf yang sama tidak berbeda nyata pada uji BNT taraf $5 \%$, MST $=$ minggu setelah tanam. 
sempurna dan tidak ada penambahan bahan organik tanah sehingga kondisi tanah lebih masam dan hal tersebut dapat menyebabkan kejenuhan $\mathrm{Al}$ dan $\mathrm{Fe}$ lebih tinggi sehingga unsur $\mathrm{P}$ banyak terikat oleh $\mathrm{Al}$ dan Fe. Hal tersebut menyebabkan unsur P tersedia tanah menjadi rendah serta hanya sedikit hara yang dapat diserap tanaman.

\subsubsection{Kalium (K)}

Tabel 7 menunjukkan hara $\mathrm{K}$ terangkut tertinggi pada polong, daun, dan batang terdapat pada perlakuan T0 yaitu $2,77 \mathrm{~kg}$ ha-1, 1,27 kg ha1 , dan $8,01 \mathrm{~kg}$ ha-1. Tingginya hara $\mathrm{K}$ terangkut dapat disebabkan oleh penggunaan mulsa pada OTM yang dapat memberikan ketersediaan hara. Menurut Oktaviansyah (2015) olah tanah minimum + herbisida menghasilkan serasah gulma yang dapat meningkatkan kelembaban tanah serta tidak terjadi persaingan dengan gulma dalam penyerapan unsur hara $\mathrm{K}$. kelembaban dan aerasi tanah, total pasokan hara, suhu tanah, serta sifat fisik maupun sifat kimia tanah mempengaruhi ketersediaan hara didalam tanah (Olson dan sander, 1988).

\subsubsection{Karbon (C) tanaman}

Tabel 8 menunjukkan hara $\mathrm{C}$ terpanen pada polong tertinggi terdapat pada perlakuan $\mathrm{P} 1$ yaitu $0,07 \mathrm{Mg}$ ha- 1 . Hal ini terjadi karena dengan adanya penambahan pupuk maka ketersediaan hara di dalam tanah juga ikut meningkat. Dengan adanya peningkatan ketersediaan hara maka serapan hara juga ikut meningkat diikuti dengan proses fotosintesis atau hasil asimilasi yang tinggi. Hal ini sejalan dengan pendapat Sutedjo (2002) bahwa pemberian pupuk anorganik ke dalam tanah dapat menambah ketersediaan hara yang cepat bagi tanaman.

Tabel 8 menunjukkan hara $\mathrm{C}$ terpanen pada daun dan batang tertinggi terdapat pada perlakuan T0 yaitu $0,04 \mathrm{Mg}$ ha-1 dan 0,16 Mg ha-1. Hal ini disebabkan karena pada olah tanah intensif semua struktur tanah disekitar tanaman terganggu karena diolah, sehingga aliran serapan pupuk terganggu (Wardoyo, 2008), karena struktur tanah terganggu sehingga unsur hara yang diberikan ke tanaman juga akan terganggu proses penyerapannya dan sedikit hasil asimilasi yang diperoleh.

Tabel 7. Pengaruh Olah Tanah dan Pemupukan terhadap Hara K Terangkut pada Tanaman Kacang Hijau.

\begin{tabular}{|c|c|c|c|c|c|}
\hline \multirow{2}{*}{ Perlakuan } & \multicolumn{5}{|c|}{ Hara $\mathrm{K}$ terangkut $\left(\mathrm{kg} \mathrm{ha}^{-1}\right)$} \\
\hline & Biji & Polong & Daun & Batang & Total \\
\hline T0 (olah tanah minimun) & 12,35 & $2,77 \mathrm{a}$ & $1,27 \mathrm{a}$ & $8,01 \mathrm{a}$ & 24,40 \\
\hline T1 (olah tanah intensif) & 13,70 & $2,17 \mathrm{~b}$ & $0,87 \mathrm{~b}$ & $5,82 \mathrm{~b}$ & 22,56 \\
\hline UJI F & tn & $*$ & $*$ & $*$ & tn \\
\hline BNT 5\% & - & 0,57 & 0,28 & 1,72 & - \\
\hline P0 (tanpa pupuk) & 12,06 & 2,45 & 1,11 & 7,21 & 22,83 \\
\hline P1 (pemberian pupuk) & 13,98 & 2,49 & 1,03 & 6,61 & 24,11 \\
\hline UJI F & tn & tn & tn & tn & tn \\
\hline BNT 5\% & - & - & - & - & - \\
\hline
\end{tabular}

Keterangan $:$ tn $=$ tidak berbeda nyata pada taraf $5 \%, *=$ berbeda nyata pada taraf $5 \%$, Kolom yang diikuti dengan huruf yang sama tidak berbeda nyata pada uji BNT taraf $5 \%$, MST $=$ minggu setelah tanam.

Tabel 8. Pengaruh Olah Tanah dan Pemupukan terhadap Hara C Terpanen pada Tanaman Kacang Hijau.

\begin{tabular}{|c|c|c|c|c|c|}
\hline \multirow{2}{*}{ Perlakuan } & \multicolumn{5}{|c|}{ Hara $\mathrm{C}$ terpanen $\left(\mathrm{Mg} \mathrm{ha}^{-1}\right)$} \\
\hline & Biji & Polong & Daun & Batang & Total \\
\hline T0 (olah tanah minimun) & 0,14 & 0,07 & $0,05 \mathrm{a}$ & $0,16 \mathrm{a}$ & 0,41 \\
\hline T1 (olah tanah intensif) & 0,14 & 0,06 & $0,03 \mathrm{~b}$ & $0,11 \mathrm{~b}$ & 0,34 \\
\hline UJI F & tn & tn & $*$ & $*$ & tn \\
\hline BNT 5\% & - & - & 0,01 & 0,03 & - \\
\hline P0 (tanpa pupuk) & 0,13 & $0,06 \mathrm{~b}$ & 0,03 & 0,14 & 0,36 \\
\hline P1 (pemberian pupuk) & 0,16 & $0,08 \mathrm{a}$ & 0,03 & 0,14 & 0,40 \\
\hline UJI F & tn & $*$ & tn & tn & tn \\
\hline BNT 5\% & - & 0,01 & - & - & - \\
\hline
\end{tabular}

Keterangan : $\mathrm{tn}=$ tidak berbeda nyata pada taraf $5 \%, *=$ berbeda nyata pada taraf $5 \%$, Kolom yang diikuti dengan huruf yang sama tidak berbeda nyata pada uji BNT taraf $5 \%$, MST = minggu setelah tanam. 


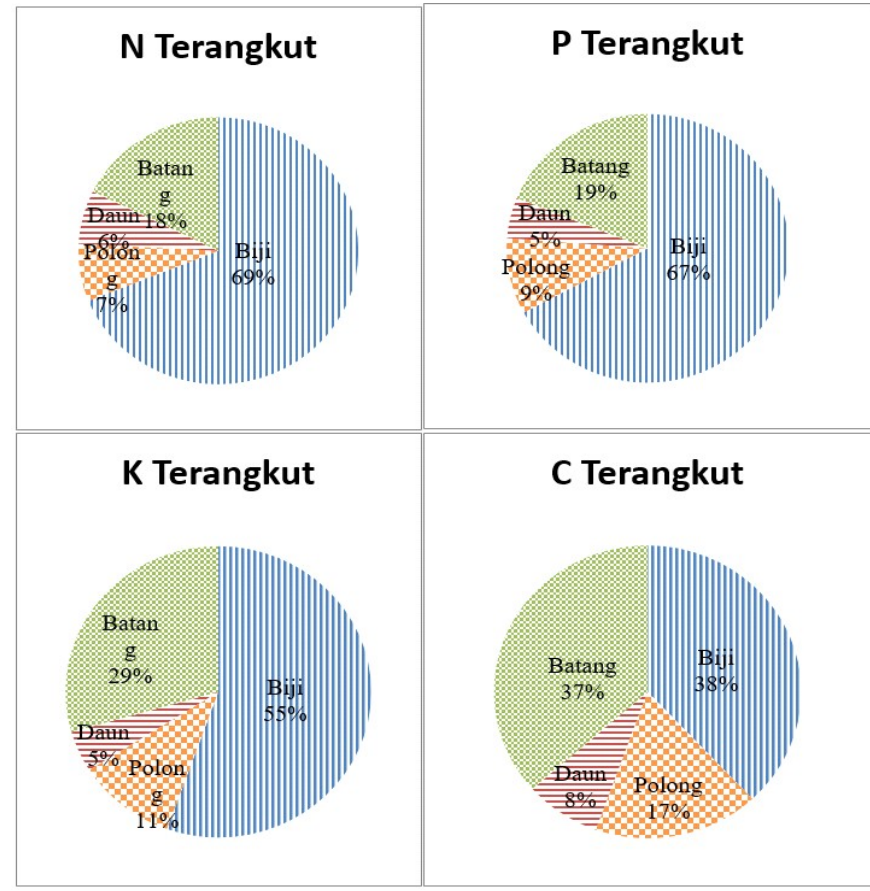

Gambar 1. Diagram Sebaran Hara C, N, P, K Terangkut pada Biji, Polong, Daun, dan Batang Tanaman Kacang Hijau.

\subsubsection{Sebaran Hara $(C, N, P, K)$ di Dalam Biomassa}

Sebaran hara C, N, P, K dalam biomassa biji, polong, daun, dan batang disajikan pada (Gambar 1). Peluang kehilangan hara meningkat sejalan dengan tingginya produksi kacang hijau. Semakin banyak produksi kacang hijau maka hara $\mathrm{N}, \mathrm{P}, \mathrm{K}$, dan $\mathrm{C}$ yang terangkut juga semakin banyak. Hara N, , $\mathrm{K}$, dan $\mathrm{C}$ dalam biji kacang hijau akan terangkut sewaktu panen yang selanjutnya digunakan untuk dikonsumsi. Hara N, P, K, dan C yang terdapat pada daun, batang, dan polong biasanya akan terangkut saat panen kecuali pada petak dengan olah tanah minimun. Pada olah tanah minimum sisa panen dikembalikan lagi ke petak percobaan untuk dijadikan mulsa. Hara yang terdapat pada sisa - sisa tanaman di lahan tersebut akan kembali tersedia setelah sisa tanaman tersebut terdekomposisi oleh mikroorganisme tanah. Sebagian hara mengalami perputaran dan sebagian lagi keluar dari sistem perputaran tergantung kepada jumlah hara yang diberikan melalui pupuk dan sumber lain atau cara panen.

\section{KESIMPULAN}

Berdasarkan penelitian yang dilaksanakan, dapat disimpulkan bahwa perlakuan olah tanah minimum berpengaruh nyata terhadap bobot kering batang, hara $\mathrm{N}$ terangkut (biji, daun, batang, dan total), hara $\mathrm{P}$ terangkut (batang dan total), hara $\mathrm{K}$ terangkut (polong, daun, dan batang), serta hara $\mathrm{C}$ terpanen (daun dan batang) yang lebih tinggi dibandingkan perlakuan lainnya. Perlakuan pemupukan pupuk majemuk NPK $200 \mathrm{~kg}$ ha-1 dan kompos $1 \mathrm{Mg}$ ha-1 berpengaruh nyata terhadap tinggi tanaman, produksi biji kacang hijau, bobot kering biji kacang hijau, hara P terangkut (biji dan polong), serta hara $\mathrm{C}$ terpanen (polong) yang lebih tinggi dibandingkan perlakuan lainnya. Tidak terdapat pengaruh interaksi antara perlakuan olah tanah dan pemupukan terhadap pertumbuhan, produksi, dan hara terangkut $(\mathrm{C}, \mathrm{N}, \mathrm{P}, \mathrm{K})$ tanaman kacang hijau.

\section{UCAPAN TERIMA KASIH}

Penelitian ini merupakan bagian dari skripsi program sarjana jurusan Agroteknologi Fakultas Pertanian Universitas Lampung.

\section{DAFTAR PUSTAKA}

Anang, S., Soedradjad, dan A. Majid. 2010. Aktivitas Nitrogenase Bintil Akar pada Tanaman Kedelai (Glycine max L.) yang Berasosiasi dengan Bakteri Fotosintetik 
Synechococus sp. Penelitian Fundamental. Universitas Jember. Jember.

Badan Pusat Statistika. 2019. Kacang Hijau. Katalog BPS. Jakarta. $7 \mathrm{hlm}$.

Halvin, J. L., S. M. Tisdale., W. L. Nelson and J.D Beaton 1999. Soil Fertility and Fertilizer an Introduction to Nutrient Management. Prentice Hall. 499.

Kariyasa, K. 2005. Integrasi Tanaman-Ternak dalam Perspektif Reorientasi Kebijakan Subsidi Pupuk dan Peningkatan Pendapatan Petani. Analisis Kebijakan Pertanian, 3 (1): 68-80

Kaya, E. 2013. Pengaruh Kompos Jerami dan Pupuk NPK terhadap N-Tersedia Tanah, Serapan N, Pertumbuhan, dan Hasil Padi Sawah (Oryza sativa L.). Jurnal Ilmu Budidaya Tanaman Agrologia, 1(1): 1-9.

Kusumastuti, A., Fatahillah, A. Wijaya, dan Y. Sukmawan. 2018. Pengaruh Olah Tanah dan Residu N Tahun ke 29 pada Beberapa Sifat Kimia Tanah dengan Tanaman Indikator Leguminosa. Journal of Applied Agricultural Science, 2(1): 2-29.

Meirina, T., S. Darmanti, dan S. Haryati. 2009. Produktivitas Kedelai (Glycine max L. Merril) Var. Lakon yang Diperlakukan dengan Pupuk Organik Cair Lengkap pada Dosis dan Waktu Pemupukan yang Berbeda. Ejournal Universitas Diponegoro. Semarang. $14 \mathrm{hlm}$.

Nainggolan, A., B. Guritno, dan T. Islami. 2017. Pengaruh Olah Tanah dan Pemupukan terhadap Pertumbuhan dan Hasil Tanaman Kedelai (Glycine max (L.) Merill). Jurnal Produksi Tanaman, 5(6): 999-1006.

Oktaviansyah, H. 2015. Pengaruh Pengolahan Tanah terhadap Pertumbuhan, Produksi, dan Serapan Hara jagung (Zea mays) pada Periode Tanam Pertama di Gedung Meneng Bandar Lampung. Skripsi Universitas Lampung. Bandar Lampung. $75 \mathrm{hlm}$.

Olson, R.A., and D.H. Sander. 1988. Corn Production. In Monograph Agronomy Corn and Corn Improvement. Wisconsin. 639-686.

Rachman, A., A. Dariah, dan E. Husen. 2004. Konservasi Tanah Pada Lahan Kering Belerang. Pusat Penelitian dan Pengembangan Tanah dan Agroklimat. Badan Litbang Pertanian. $204 \mathrm{hlm}$.

Sirappa, M. P., Arafah., dan R. Nasruddin. 2005. Kajian Penggunaan Pupuk Organik dengan Berbagai Dosis Pupuk Anorganik terhadap Pertumbuhan dan Hasil Padi varietas Gilirang di Lahan Sawah Irigasi. Jurnal Agrivor, 5(1): 46-54.

Sutedjo, M. M. 2002. Pupuk dan Cara Pemupukan. Penerbit Rineka Cipta. Jakarta. $177 \mathrm{hlm}$.

Sutedjo, M. M. dan A. G. Kartasapoetra. 2010. Pengantar Ilmu Tanah: Terbentuknya Tanah dan Tanah Pertanian. Rineka Cipta. Jakarta. $98 \mathrm{hlm}$.

Thom, W. O. dan Utomo, M. 1991. Manajemen Laboratorium dan Metode Analisis Tanah dan Tanaman. Universitas Lampung. Bandar Lampung. $85 \mathrm{hlm}$.

Utomo, M. 1995. Kekerasan Tanah dan Serapan Hara Tanaman Jagung pada Olah Tanah: Konservasi Jangka Panjang. Jurnal Tanah Tropika, 1: 1-7.

Wardoyo, S.S. 2008. Aplikasi Olah Tanah Konservasi dan Pupuk N pada Entisol serta Pengaruhnya Terhadap serapan NPK Tanaman Jagung. Jurnal Agrin. 12 (2): 227-236. 